\title{
チャの根におけるサイトカイニン活性の変動とその分離
}

\author{
農林水産省茶業試験場
}

津志田藤二郎・竹 尾 忠一

\section{Separation of Cytokinin-like Substances from the Root of Tea and the Changes in the Content during Sprouting of Tea Shoots}

\author{
By Tōjirō Tsushida and Tadakazu TAKEO \\ National Research Institute of Tea
}

\section{1 はじめに}

前報では茶芽に批るサイトカイニン活性の検出と, その生肓に伴う変動について報告した。しかし, サイト カイニンを活発に合成する 部位は根であるとする報告す 多数あり，根に拁けるサイトカイニン活性の変動と芽の 生育との関係を明らか炕することは，重要であると考え た。そこで今回は茶芽の萠芽前後に扔ける根のサイトカ イニン活性の変動を調查するとともに，その分離精製を 試みた。

\section{2 実 験 方 法}

\section{1 サイトカイニン活性の測定法} 前報に準じた。

\section{2 サイトカイニン様物質の抽出と精製}

(1) サイトカイニン様物質の抽出

当試験場のさし木漛埸から 1 年生苗を 2 月20日から, 4月20日まで計 7 回40 70本ずつ掘り取り，その根を洗 浄した後水を充分ふき取り，メタノールを加えてミキサ 一で摩砕抽出した。な拉，朋いた根はすべて根幹部を除 いたものである。得られた摩研液を東洋 No. 2 万紙でろ

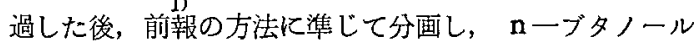
で抽出されたA画分について，ポリビニールピロリドン カラムクロマトグラフィーを行い，溶出液のサイトカイ ニン活性を測定した。サイトカイニン様物質の分離精製 には 2 年生苗の根を用い, 同様にメタノール抽出した後 $\mathrm{A}$ 画分を調整した。

$$
\begin{aligned}
& \text { (2) セファデックス LH20 カラムクロマトグラ } \\
& \text { フィー }
\end{aligned}
$$

$2 \mathrm{~cm} \times 90 \mathrm{~cm}$ のカラムにセファデックス LH20を 35 \%ェタノール溶液にけん濁して詰めた後, 同溶液でしば らく洗浄した。このカラムイA画分溶液を添加し, 同溶 液で溶出した。溶出液量は $1.57 \mathrm{~m} l / \mathrm{min}$ であり, $20 \mathrm{~g}$ ずつ分画し，濃縮して，アルコールを除去した後，M/75
リン酸紘衝液で一定量にし，そのサイトカイニン活性を 測定した。

(3) シリカゲル薄層クロマトグラフィー

ワコーゲル B-10 $20 \mathrm{~cm} \times 20 \mathrm{~cm}$ のガラスプレー トに $0.50 \mathrm{~mm}$ の厚さで染布し，常法ぞ批り活性化させ

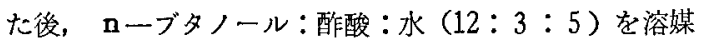
として用い，室温で展開した。展開終了後充分乾燥し， 各 Rf ごとにかき取り， $80 \%$ メタノールで2回抽出し， 減圧濃縮した後, $M / 75$ リン酸綏衙液を加え, サイトカ イニン活性を測定した。

ポリビニールピロリドンカラムクロマトグラフィー, ペーパークロマトグラフィーは前報に準じた。

\section{3 結果および考察}

\section{1 チャの根におけるサイ,トカイニン活性の萌茅 前後での活性変動}

因 1 は萠芽前後に拈けるチャの根のメタノール抽出物 のA画分のサイトカイニン活性をポリビニールピロリド ンカラムで分離した結果を示すすのである。いずれの場 合もフラクション番号 $3 \sim 4$ 本に強い活性が検出され た。この溶出位置は天然界に存在するサイトカイニンで あるゼアチン、リボシルゼアチンの溶出位置と一致して いた。

表 1 にはベンジルアデニン相当量に 換算した各時期の 根におけるサイトカイニン含量を生鮮重当りで示した。 これによると3月14日頃に根におけるサイトカイニン濃 度が最高になり，以後減少していることがかかる。他方， 苗1本当りのサイトカイニン含量は 4 月 4 日に最す高く なり以後隇少した。萠芽は4月4日であった。4月4日 に拔ける根のサイトカイニン含量はベンジルアデニン相 当量で $0.05 \mu \mathrm{g}$ であり 2 月 20 日の 2.6 倍であった。また この時期における根の生長も著しく，4月20日には $11.4 \mathrm{~g}$ となり，2月20日の約 2 倍になった。

萌芽前に括ける根のサイトカイニンの増加，と萠芽後 
茶業研究報告
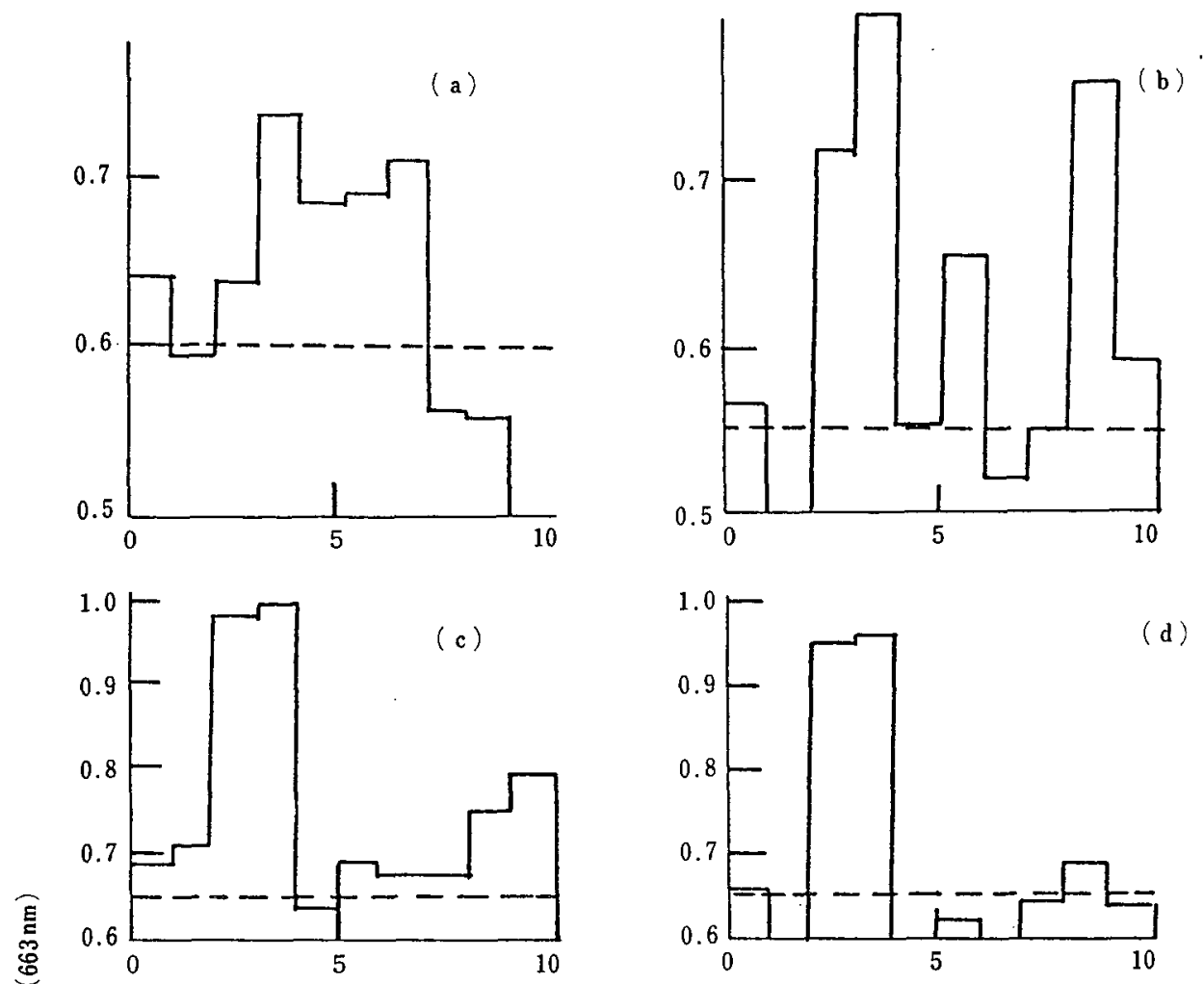

些
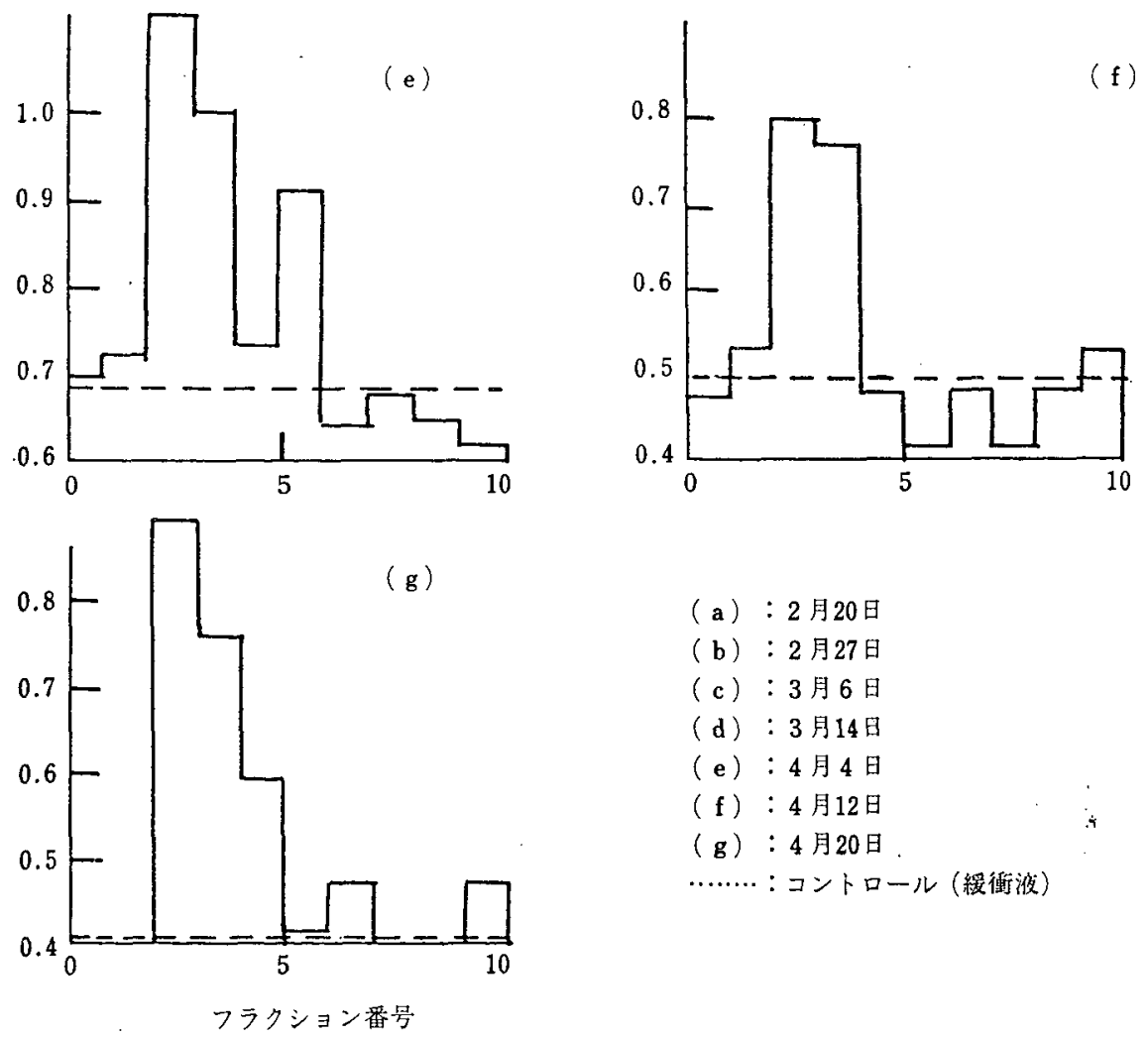
(a) : 2 月20日
(b) : 2 月27日
(c) : 3 月 6 日
(d) : 3 月14日
(e) : 4 月 4 日
(f) : 4 月12日
(g)：4月20日
……… コントロール (緩衝液)

図 1 チャの根のA 画分のポリビニールピロリドンカラムクロマトグラフィーによる 溶出パターンの萠芽前後に淤ける変動 
に抢ける隇少はポプラに拈いてもすでに観察されてい る。HEWETT 等は樹液のサイトカイニンの変動る同時 に調查することにより，新芽へ根で合成されたサイトカ イニンが移動することを推定している。

\section{2 チャの根のサイトカイニン樣物質の分離と}

\section{精製}

種々のクロマトグラフィーを用いてA画分のサイトカ イニン様物質を分離精製した。図2 にはセファデックス LH 20 カラムクロマトグラフィーの結果を示した。この 方法ではA画分比けるサイトカイニン活性は三つのグ ループに分けることが出来た。図 3 にはポリビニールピ

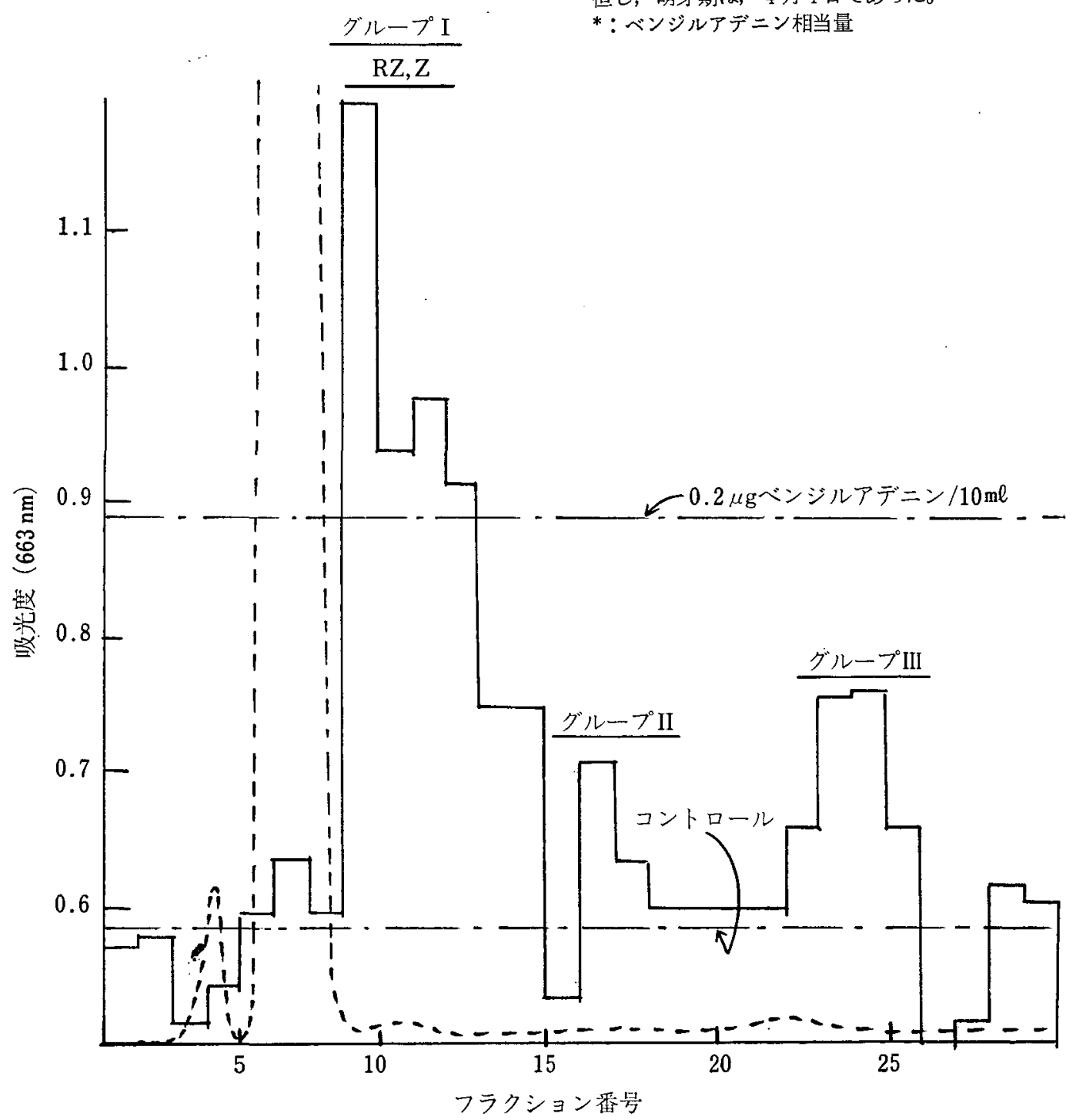

図2 セファデックス LH20 カラムクロマトグラフィーによるA画分の分離とそのサイトカイニン活性

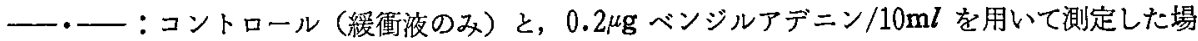
合のクロロフィル合成量

.... : $260 \mathrm{~nm}$ 吸収 $Z$ : ゼアチン $\mathrm{RZ}:$ リボシルゼアチン
表 1 萌芽前後におけるチャの根の サイトカイニン含量の変動

\begin{tabular}{|c|c|c|c|c|}
\hline \multirow{2}{*}{ 掘取 日 } & \multirow{2}{*}{$\begin{array}{c}\text { 本数 } \\
\text { 本 }\end{array}$} & \multirow{2}{*}{$\begin{array}{c}\text { 重 量 } \\
\mathrm{g} / \text { 本 }\end{array}$} & \multicolumn{2}{|c|}{ サイトカイニン* } \\
\hline & & & $\mu \mathrm{g} / \mathrm{kg}$ & $\mu \mathrm{g} /$ 本 \\
\hline 2月20日 & 55 & 5.64 & 2.23 & 0.0125 \\
\hline 2 月27日 & 56 & 5.36 & 4.37 & 0.0233 \\
\hline 3 月6日 & 54 & 8.89 & 4.79 & 0.0426 \\
\hline 3 月14日 & 50 & 8.00 & 5.46 & 0.0437 \\
\hline 4 月 4 日 & 46 & 11.24 & 5.03 & 00.565 \\
\hline 4 月 12 日 & 40 & 11.36 & 3.39 & 0.0386 \\
\hline 4 月20日 & 65 & 11.40 & 2.83 & 0.0323 \\
\hline
\end{tabular}

但し，萌芽期は，4月 4 日であった。

*:ベンジルアデニン相当量 


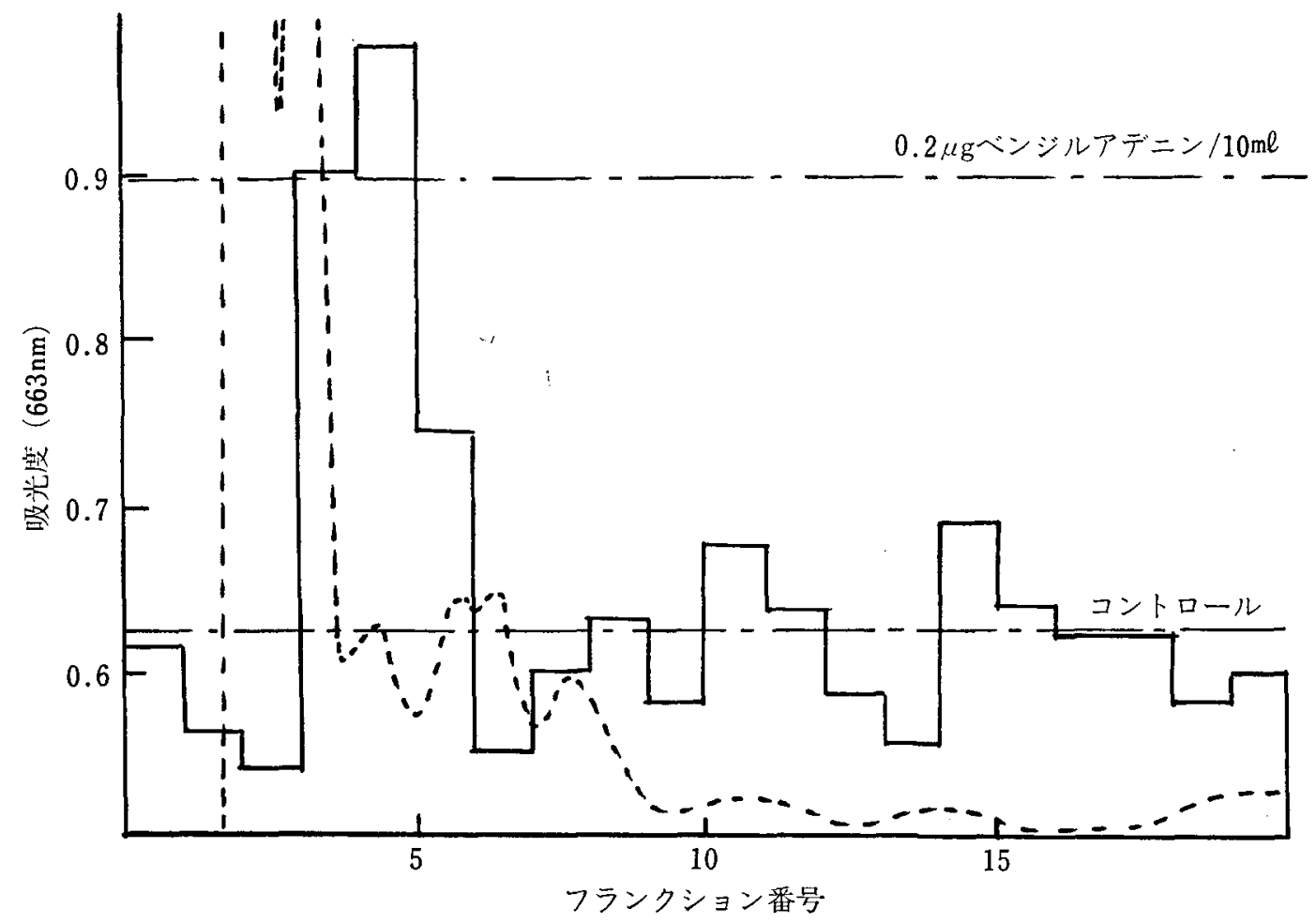

図3 ポリビニールピロリドンカラムクロマトグラフィによるA画分の分離とそのサイトカイ二ン活性 .....: : $260 \mathrm{~nm}$ 吸收

ロリドンカラムクロマトグラフィーの結果を示した。こ の場合わやはり A画分のサイトカイニン活性は三つのグ ループに分けることが出来た。双方のクロマトグラフィ 一で得られた最初の活性ピークは，いずれるゼアチンと リボシルゼアチンの溶出位置と一致していた。しかし， 他の二っのピークは不明であった。次沉ペーパークロマ トグラフィーにより分離した結果を図4亿示した。 $\mathrm{n}$ 一 ブタノール:酢酸：水 $(12: 3: 5)$ を展開溶媒にした 場合は Rf 0.8 付近火強いサイトカイニン活性が得られ た純品のゼアチンを同様に展開した結果と Rf 值がほほ 一致した。また $0.3 \mathrm{M}$ ホウ酸緩衝液（pH 8.3）を展開溶 媒として用いたところ，Rf 0.65 付近に強い活性が得ら れ，Rf 0.8 以上代は活性が得られなかった。 Rf 0.65 K はゼアチンが 展開されることが明らか炕なっている。以 上より根には主として各種クロマトグラフィーに㧍ける 挙動がゼアチンと類似した 化合物が存在することが推定 された。次化ポリ゙ニールピロリドンカラムクロマトグ ラフィーで得られた活性画分 (フラクション番号 3〜4) を漂縮して，シリカゲル薄層クロマトグラフィーを行っ た結果を図 5 に示した。この場合もRf 值はゼアチンと 情湾一致していた。この活性画分をかき取り，80\%エタ ノールで抽出し，再びポリビニールピロリドンカラムク ロマトグラフィーで分離した結果を図6に示した。(b) は その溶出パターンを示したものであるが二つのピークに

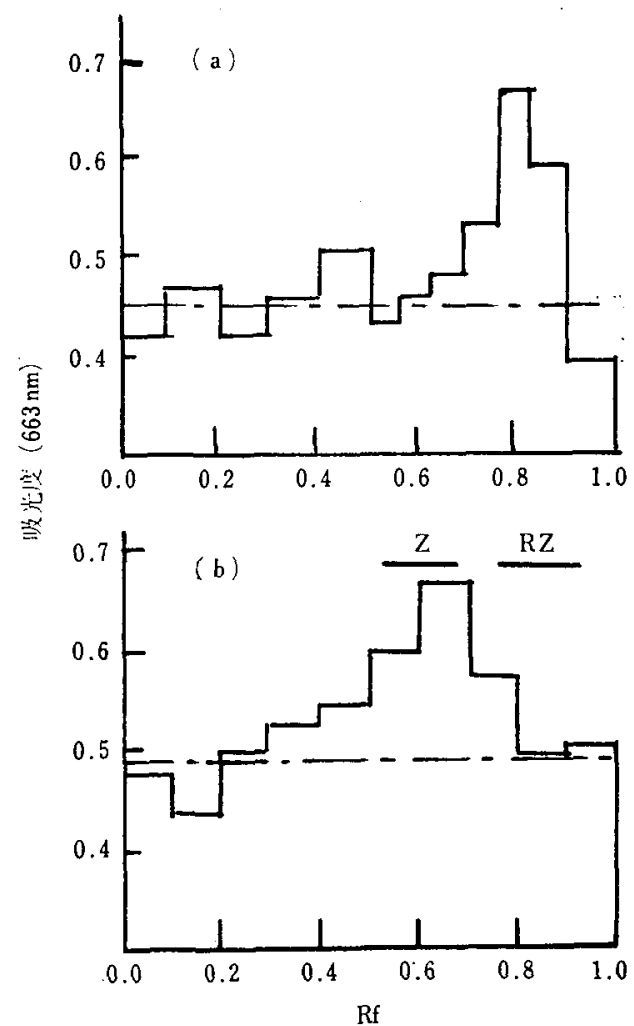

図 4 A画分のペーパークロマトグラフィーによる分離 とそのサイトカイニン活性の分布

(a) : 展開溶媒, $\mathrm{n}$ 一ブタノール:酢酸：水 (12:3:5)

(b)：展開溶媒， $0.3 \mathrm{M}$ ホウ酸緩衝液 ( $\mathrm{pH} 8.3$ ) 


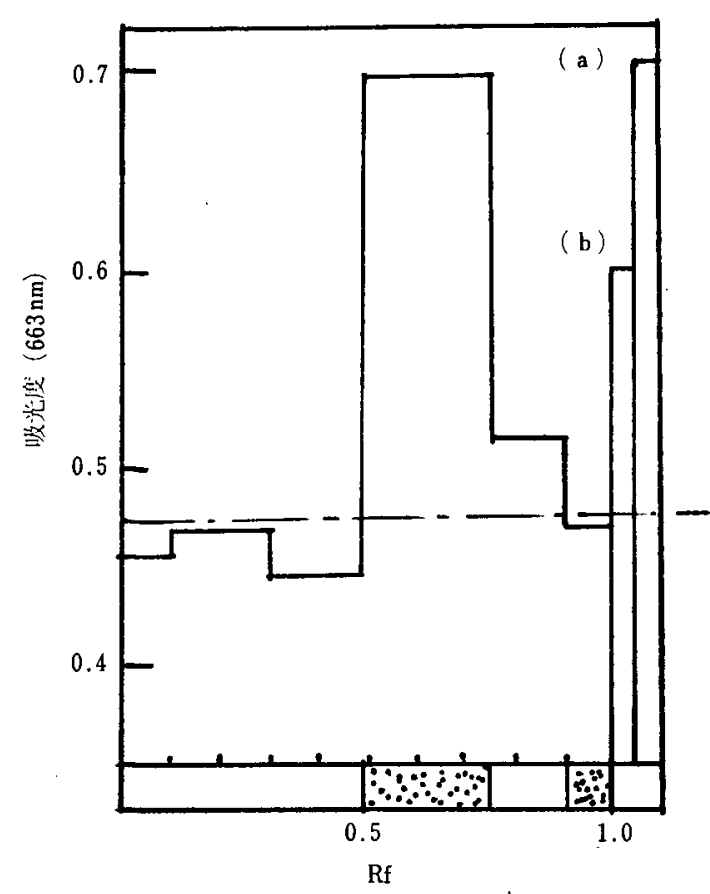

因 5 ポリビニールピロリトンカラムクロマトグラフ ィーで分離した活性画分のシリカゲル薄層クロ マトグラフィーによる分離と, そのサイトカイ ニン活性
(a) : ベンジルアデニン溶液 $0.2 \mu \mathrm{g} / 10 \mathrm{~m} l$ (b) : ベンジルアデニン溶液 $0.4 \mu \mathrm{g} / 10 \mathrm{~m} l$
: 紫外線吸収

分れた。最初のピークは $272 \mathrm{~nm}$ に極大吸収を持ち，カ ェフインと吸収スペクトラムが一致した。他方のピーク は極大吸収が $268 \mathrm{~nm}$ にあり, 市販のゼアチンと極大吸 収が一致していた。しかし吸収スペクトラムは市販のも のに比べ，極大吸収付近のピークがブロードであり，不 純物の混入が予想された。(b) は市販のカフェインとゼア チンを混入して同様に溶出した結果であるが，(a) とよく 一致した。

以上のことからチャの根に拁けるサイトカイニン様物 質の主体は，ゼアチンであることが推定された。

\section{4 要約}

チャの根におけるサイトカイニン活性の変動を萠芽前 後に 7 回調查した。この結果萌芽前に根のサイトカイニ ン濃度が高くなり, 萌芽後には減少すること, 苗の根 1 本当りのサイトカイニン量は萌芽期㵊多多く，以後減 少することが明らか炏なった。

セフォデックス LH 20，ポリビニールピロリドンカラ ムクロマトグラフィーの結果より， $\mathrm{n}$ 一ブタノール抽 出されるA画分には，少くとも三種のサイトカイニンが 存在することが明らかになった。この中で最も活性量の 高いフラクションは, ペーパークロマトグラフィー, 薄

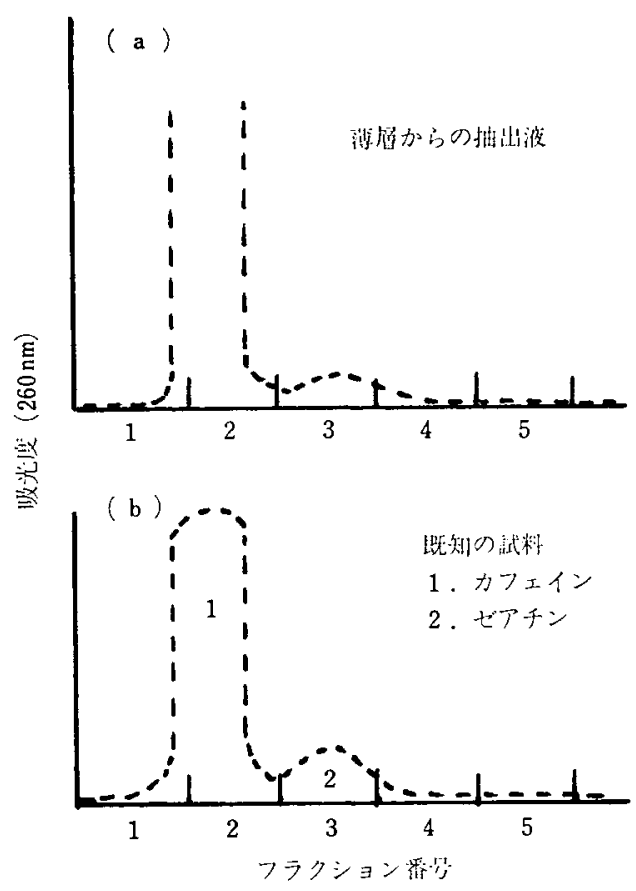

図6 薄層クロマトグラフィー分離した活性画分の ポリビニールピロリドンクラムクロマトグラ フィーの溶出パターン

層クロマトグラフィーなどで，ゼアチンと類似した挙動 を示すことが明らかになった。薄層クロマトグラフィー で分離した活性画分を再び，ポリビニールピロリドンカ ラムクロマトグラフィーで精製し，その吸収スペクトラ ムをゼアチンと比較したところ, 極大吸収が $268 \mathrm{~nm}$ に あり一致した。

\section{5 文献}

1) 津志田藤二郎, 竹尾忠一 : 茶研報, No. 54.(1981).

2) Hewett E. W., and P.F. Wareing : Pyhsiol. Plant., 28, 393 399 (1973).

3) Hewett E. W., and P.F. Wareing : Physiol. Plant., 29, 386 389 (1973).

4）臀田隆治，折谷隆志：日作記，43，47 51 (1974).

\section{Summary}

The concentration of cytokinin in the roots increased before sprouting of new shoots, and gradually decreased after sprouting. The amount of cytokinin in the roots reached to the highest value at the just sprouting stage.

It was clarified by sephadex LH 20 column 
chromatography and polyvinyl-pyrolidone column chromatography that the fraction $A$ extracted by n-butanol from basic aqueous soluiton of the root homogenate had at least three kinds of cytokinin-like substances. Rfs of the main cytokinin-like substances found in the root extract on paper chromatogram and thin-layer chromatogram were same as those of zeatin. The UV spectrum of the purified substance had a maximun absorption at $268 \mathrm{~nm}$ and coincided with that of zeatin.

(Sep. 29, 1981) 